\title{
Polychaete (Annelida) Diversity Patterns in Southern Gulf of Mexico: The Influence of Spatial Structure and Environmental Variables
}

\author{
Benjamín Quiroz-Martínez $^{1, *(\mathbb{D})}$, Pablo Hernández-Alcántara ${ }^{2}$ (D), David Alberto Salas-de-León ${ }^{3}$ (D) \\ and Vivianne Solís-Weiss ${ }^{4}$
}

check for updates

Citation: Quiroz-Martínez, B.; Hernández-Alcántara, P.

Salas-de-León, D.A.; Solís-Weiss, V. Polychaete (Annelida) Diversity Patterns in Southern Gulf of Mexico: The Influence of Spatial Structure and Environmental Variables. Diversity 2021, 13, 425. https://doi.org/ 10.3390/d13090425

Academic Editor: Bert W. Hoeksema

Received: 22 June 2021

Accepted: 5 August 2021

Published: 3 September 2021

Publisher's Note: MDPI stays neutral with regard to jurisdictional claims in published maps and institutional affiliations.

Copyright: (c) 2021 by the authors. Licensee MDPI, Basel, Switzerland. This article is an open access article distributed under the terms and conditions of the Creative Commons Attribution (CC BY) license (https:// creativecommons.org/licenses/by/ $4.0 /)$.
1 Laboratorio de Ecología Numérica y Análisis de Datos, Instituto de Ciencias del Mar y Limnología, Universidad Nacional Autónoma de México, Circuito Exterior S/N, Cd. Universitaria, Ciudad de Mexico 04510, Mexico

2 Laboratorio de Ecología y Biodiversidad de Invertebrados Marinos, Instituto de Ciencias del Mar y Limnología, Universidad Nacional Autónoma de México, Circuito Exterior S/N, Cd. Universitaria, Ciudad de Mexico 04510, Mexico; pabloh@cmarl.unam.mx

3 Laboratorio de Oceanografía Física, Instituto de Ciencias del Mar y Limnología, Universidad Nacional Autónoma de México, Circuito Exterior S/N, Cd. Universitaria, Ciudad de México 04510, Mexico; dsalas@unam.mx

4 Laboratorio de Ecología y Biodiversidad de Invertebrados Marinos, Unidad Académica de Sistemas Arrecifales, Instituto de Ciencias del Mar y Limnología, Universidad Nacional Autónoma de Mexico, Prol. Av. Niños Héroes s/n, Puerto Morelos 77580, Mexico; solisw@cmarl.unam.mx

* Correspondence: bquirozm@cmarl.unam.mx

\begin{abstract}
A comprehensive database was built to examine the spatial diversity patterns of polychaete species from the continental shelf in Southern Gulf of Mexico. Using Cluster and nMDS analysis we found the composition of polychaete species to be different between the terrigenous and carbonate regions of the Gulf. To test the relative importance of spatial and environmental components in the polychaetae community structure in the Southern Gulf of Mexico, we examined the spatial relationships between polychaetae assemblages and environmental variables over broad geographical scales. A distance-based redundancy analysis (dbRDA) and variation partitioning was used to quantify the relative importance of these explanatory variables on the spatial variations of species richness and composition. Variation partitioning is an important tool to investigate the importance of spatial structure to species distribution in communities, but it has not yet been used in marine ecosystems. The significance level of spatial and environmental components to the distribution of polychaete species showed that the combined effect of spatial processes and sediment characteristics explained a higher percentage of variance than those parameters could alone.
\end{abstract}

Keywords: polychaeta; Southern Gulf of Mexico; distance-based redundancy analysis; variation partitioning

\section{Introduction}

The study of patterns of biodiversity has increased remarkably over the last few years. In marine soft sediments, the spatial distribution of species is crucial to understanding the interactions of species with each other and with the environment [1].

Characterizing the mechanisms that structure ecological communities is fundamental to a better understanding of ecosystems' functioning [2,3]. The relationship between the composition of a species and the inclusion of the environmental components into analysis of that community is a common subject in community ecology studies and has been increasingly used in the study of marine ecosystems and benthic ecology [4-8]. The inclusion of this component in community analysis can help detect any spatially dependent organization that species may display [2]. 
One of the major goals of ecology is trying to explain the causes of variation in biodiversity at multiple spatial scales and relating these fluctuations to changes in environmental drivers, and this is becoming an increasingly important task $[9,10]$. Different methods exist that take the spatial component into consideration in community analysis [11,12]. A notable example is the use of ordination analysis in order to partition out the variance of different sets of variables $[13,14]$. This method involves evaluating environmental variables and creating a geographic coordinates matrix (spatial matrix), as well as characterizing these variables' individual and compounded contribution to the community structure. Variation partitioning has become an important exploratory tool, as it can provide an understanding of the regional and local processes that structure the communities $[3,15,16]$.

Annelida Polychaeta are among the most common and diverse groups in the macrofauna inhabiting the benthic zone. They are one of the most characteristic groups of soft-bottom benthic communities $[17,18]$ and one of the richest invertebrate benthic taxa with respect to species number $[19,20]$. This group is often dominant in benthic macrofauna [21], and is known to comprise up to $60-70 \%$ of the individuals of soft bottom macrozoobenthos $[17,22]$. Polychaetes can be used as "markers" of different ecological conditions [23] and they can be especially informative in assessing the health of benthic environments. Therefore, the analysis of the diversity patterns of this fauna can be essential to understanding how ecosystems function, since the biological processes that determine these patterns can reflect those of the entire ecosystem [24-30]. In the continental shelf of the Gulf of Mexico, polychaetes represent a key group in terms of abundance and diversity [31]. The annelid polychaete fauna of the Gulf of Mexico has been the subject of extensive research for decades, but information about the patterns of the species' distribution is still scarce. Accordingly, a comprehensive database was built, using the results of several research projects carried out in the Southern Gulf of Mexico, to examine the spatial diversity patterns in its continental shelf. Considering the high environmental heterogeneity of the Gulf of Mexico, our hypothesis is that the composition of polychaete species will be different between the terrigenous and the carbonate regions of the Gulf. To determine the relative effect of spatial and environmental components in the polychaetae community structure in the Southern Gulf of Mexico, we examined the spatial relationships between polychaetae assemblages and environmental variables using distance-based redundancy analysis (dbRDA) and variation partitioning as a means of quantifying the relative importance of these explanatory variables on the spatial variations of polychaete species' richness and composition.

\section{Materials and Methods}

\subsection{Study Area}

The study area covers approximately $46,000 \mathrm{~km}^{2}$ and is in the Southern Gulf of Mexico between the ports of Tampico, in Tamaulipas State, and Progreso, in Yucatan State $\left(18^{\circ} 30^{\prime}-22^{\circ} 20^{\prime} \mathrm{N} ; 89^{\circ} 41^{\prime}-97^{\circ} 4^{\prime} \mathrm{W}\right)$ (Figure 1). Two provinces constitute this marine region: the Bay of Campeche and the Campeche Bank. The Bay of Campeche is in the Southern Gulf, and its western region is narrow with its upper limit at $130 \mathrm{~m}$ depth, between 45 and $65 \mathrm{~km}$ offshore. The Campeche Bank, to the east, has an extensive shelf characterized by a gentle slope and uneven bottom with sandbanks, coral reefs, and autochthonous biogenic and autogenic sediments along most of the coast of the Yucatan Peninsula [32,33]. The terrigenous sediments are predominantly silty with variable amounts of gravel, sand, and clay, whereas the calcareous materials are muds constituted by fragments of shells, corals, and algae. A transitional carbonate-terrigenous region has been reported between those regions, the limits of which change throughout the year [34-36]). There are many rivers and coastal lagoons flowing in the western Gulf (terrigenous zone) whose active deposition makes sediment predominantly muddy, whereas no rivers are found in the eastern region (biogenic zone) and its sediments are mainly coarse and carbonate sand. The Southern Gulf of Mexico is a complex tropical domain with strong river discharges from the Grijalva-Usumacinta river system, which is the main source of terrigenous sediments 
in the area [36]. The adjacent coastal area is influenced by the freshwater input from this system, which modifies the salinity and temperature fields and contributes to the formation of costal hydrological fronts $[37,38]$. A cyclonic eddy dominates the mesoscale circulation in the Southern Gulf of Mexico [39,40], and modifies the position of the river plume and, as a consequence, the distribution of sediments and zooplanktonic organisms [39].

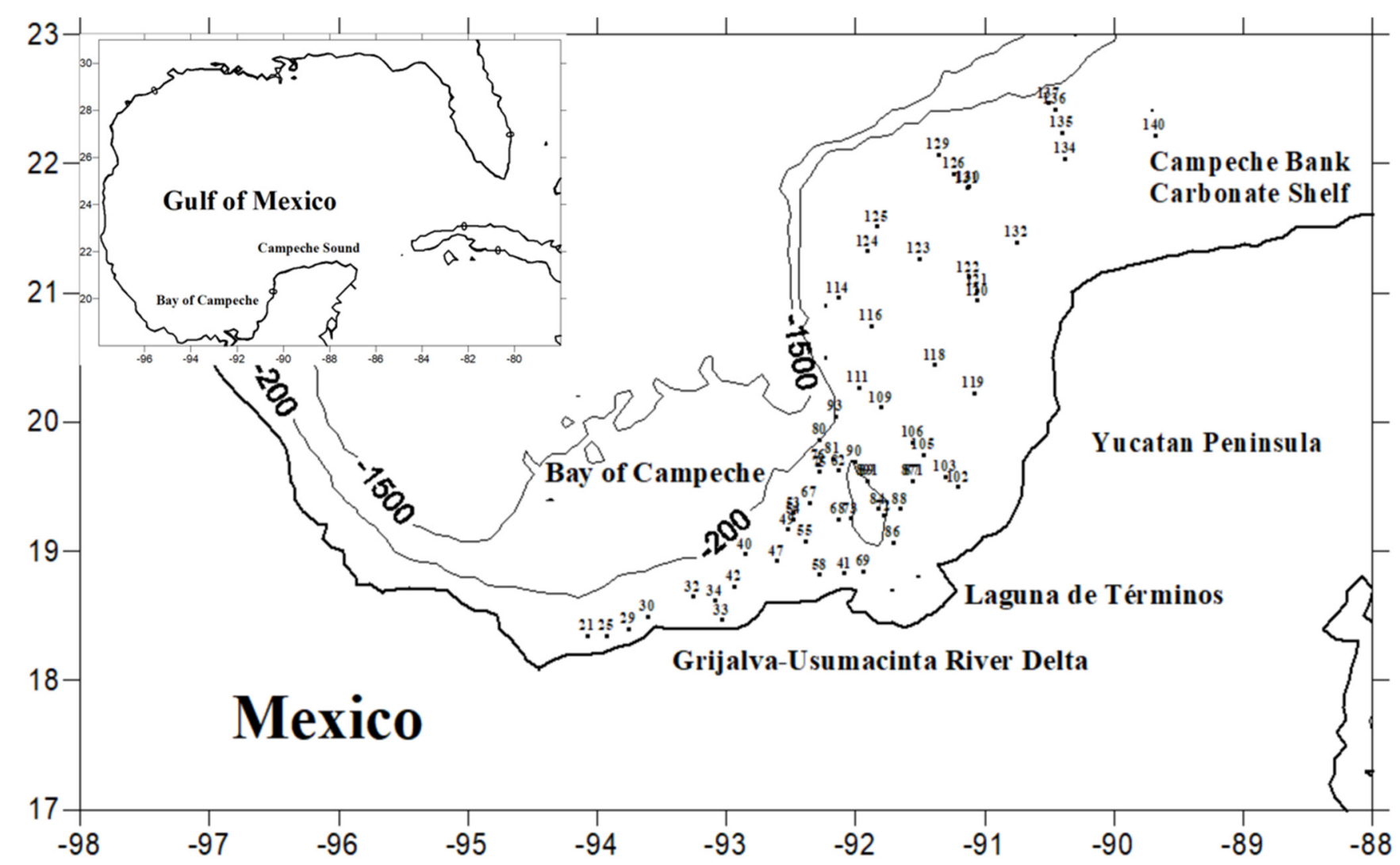

Figure 1. Sampling stations in the Southern Gulf of Mexico.

\subsection{Data Source}

The samples were taken during six oceanographic expeditions from 1988 to 1990 at depths ranging from 1 to $200 \mathrm{~m}$. A database was constructed from extensive studies carried out on the continental shelf ( $<200 \mathrm{~m}$ depth) of the Southern Gulf of Mexico $\left(18^{\circ} 30^{\prime}-22^{\circ} 20^{\prime} \mathrm{N}\right.$; $89^{\circ} 41^{\prime}-97^{\circ} 4^{\prime} \mathrm{W}$ ), as part of the institutional projects "Determination of the environmental impact caused by the oil extraction activities in the Campeche Sound, through biological, geochemical, and sedimentological studies (IMCA)" and "Ocean dynamics and their relationship to environmental damage in the Southern Gulf of Mexico (DINAMO)". The biological material was collected from 61 sampling stations, 35 in the western region (Bay of Campeche) and 26 in the eastern region (Campeche Sound), onboard the R/V "Justo Sierra" (Universidad Nacional Autónoma de México), in March and September-October 1988 and 1989 (expeditions IMCA 1, 2, 3, 4), and 1990 (expeditions DINAMO 1, 2). The same sampling strategy was used throughout the six expeditions; stations were sampled only on soft bottoms with a Smith-McIntyre grab $\left(0.1 \mathrm{~m}^{2}\right)$, collecting a volume of 20 liters of sediment at each station. The sediments were screened onboard through a $0.5 \mathrm{~mm}$ mesh to separate the macrofauna. The biological material was fixed in $4 \%$ formaldehyde. Afterwards, in the laboratory, the samples were washed to eliminate the fixative substance, then the specimens were sorted under a stereomicroscope and preserved in $70 \%$ ethanol. The polychaetes were identified to species level, catalogued, and deposited in the Colección Nacional de Anélidos Poliquetos at the Instituto de Ciencias del Mar y Limnología (ICML), UNAM (CNAP-ICML, UNAM; DFE.IN.061.0598). Stations were georeferenced with the 
ship's GPS, depth was measured with a SIMRAD ES60 echosounder, and salinity and temperature were measured close to the bottom with a Niels Brown CTD. Additional samples were taken to analyze the sedimentary texture using the sieving method (Folk 1980). Although the carbonate content was not evaluated, the differences between the east and west regions, in terms of the terrigenous and carbonate substrate, were defined by the sedimentary texture, supported by the sedimentary zonation previously reported in literature [34,41]. The resulting database included information of all identified polychaete species, their geographical distribution (latitude and longitude), and the environmental factors of depth, temperature, and salinity where they were collected. The taxonomic information was carefully checked with the more recent systematic reviews and, using the World Polychaeta database [42], the validity of names and synonymies was verified, to omit species whose taxonomic identification was doubtful or species that were sampled only once. A total of 173 species were integrated into the final database.

\subsection{Statistical Analyses}

Community dissimilarity between each pair of sampling stations was evaluated using the Sørensen dissimilarity measure, based on a presence/absence matrix. According to Baselga [43] and Carr [44], the Sørensen's dissimilarity index (ßsor) [45] provides a comprehensive vision of the beta diversity, since it takes both species loss and replacement into account [44]. The geographic distance between each pair of stations was calculated using the Euclidean distance between the longitude and latitude coordinates of each station. The environmental distance between each pair of stations was calculated using Euclidean distances based on all the environmental variables included in this study. The resulting dissimilarity matrix was used to characterize the dissimilarity patterns by means of cluster analysis (group average linkage) and non-metric multidimensional scaling (nMDS), as suggested by Field et al. [46] and Clarke and Warwick [47]. The significant differences in the assemblage structure between the two studied regions were tested with a one-way analysis of similarity (ANOSIM). Similarity percentage analysis (SIMPER) was used to identify the species defining the faunal groups, measuring the contribution of each species for similarity of assemblage [48].

The relationship between faunal pairwise dissimilarity and spatial distance was assessed by fitting an exponential function describing the increase in faunal dissimilarity with spatial distance [49,50]. To do this, an R package "betapart" (functions "decay.model" and "boot.coefs") was used, which adjusts a GLM with similarity as the response variable, spatial distance as the predictor, log link, and Gaussian error. The intercept and slope parameters were then bootstrapped (1000 replicates) [51,52].

Distance-based redundancy analysis (dbRDA) was performed to establish the relationships between community dissimilarity, spatial (geographical distances) and environmental variables (depth, temperature, salinity, sand, and mud content). Before the dbRDA analysis, forward selection procedures [53] were carried out to select the most significant spatial and environmental variables. All nonsignificant $(p>0.05)$ variables were eliminated from further analyses.

Afterwards, variation partitioning analysis was performed to assess the relative contribution of the significant spatial and environmental variables in explaining the community dissimilarity [54]. The significance of each fraction was assessed by means of a Monte Carlo permutation test. In addition, the relative contribution of each significant spatial and environmental variable in determining community dissimilarity was assessed by means of partial dbRDA, which identified the effect of each of the significant environmental/spatial variables. All analyses were run in R-4.0.3 with the "vegan" and "betapart" packages [51,55]. 


\section{Results}

\subsection{Species Composition and Distribution of Richness}

A total of 173 species, belonging to 40 families, were recorded along the continental shelf of the Southern Gulf of Mexico (Supplementary Table S1). The eastern region had the higher number of species, at 164, and in the west 125 species were collected. Polychaete species' richness varied widely throughout the study area, ranging from 12 to 57 species/station in the east (SD + 10.9) and 9 to 50 species/station in the west (SD + 11.7) (Figure 2). In average, 31.83 species/station were found in the east and 23.85 species/station were found in the west (Supplementary Figure S1).

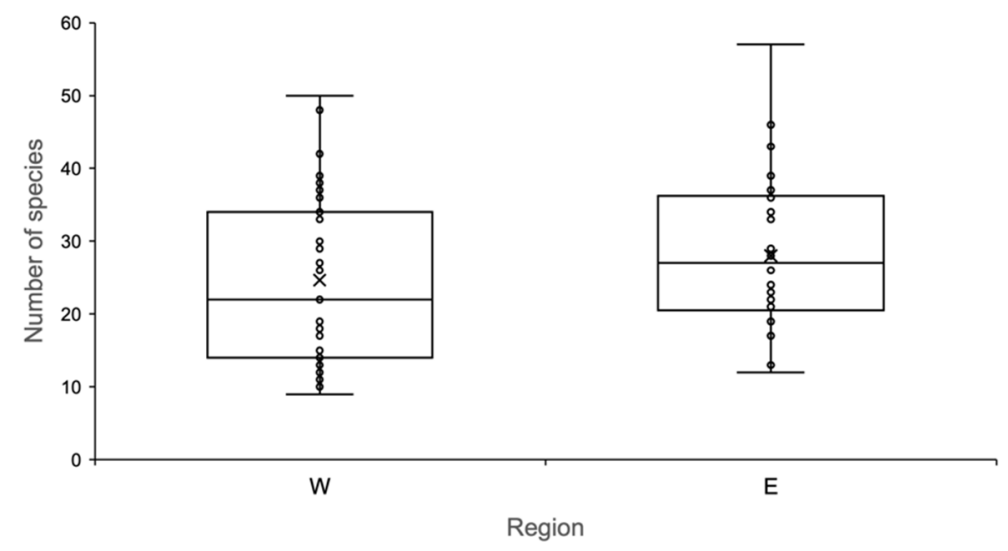

Figure 2. Box plots showing the average number of polychaete species and the minima and maxima values (whiskers) for the western (W) and eastern (E) regions of the Southern Gulf of Mexico.

\subsection{Cluster and $n M D S$ Analysis}

Analysis of dissimilarity, based on Sørensen's coefficient relating the polychaete composition of the 61 sampling stations showed two main assemblages that exhibit high dissimilarity $(>0.75$ ) between them at species level (Figure 3a,b). The ANOSIM analysis confirmed that spatial differences in the polychaete fauna were significantly related, with the two examined regions $\left(\mathrm{R}_{\text {ANOSIM }}=0.395, p=0.001\right)$. Assemblage A grouped stations located in the terrigenous region west of the Gulf of Mexico, and the most representative species were Paraprionospio sp. (11\%), Nephtys incisa (10.3\%), Scoletoma tenuis (10.3\%), and Kinbergonuphis sp. (7.3\%). Group B included stations distributed in the carbonate region on the eastern Gulf, where Scoletoma verrilli (8.5\%), Paraprionospio sp. $(8.1 \%)$, and Armandia maculata (6.1\%) were the main species defining the assemblage. The spionid Paraprionospio pinnata and, to a lesser degree, Kinbergonuphis sp., were widely distributed in the study area, but Scoletoma tenuis, Nephtys incisa, Lumbrineris cingulata, Ninoe leptognatha, and Cossura delta were mainly distributed in the west region. On the contrary, P. (P.) steenstrupi, Armandia maculata, and Scoletoma verrilli preferentially inhabited the east region (Figure $3 a, b)$.

The exponential fit between the calculated value of Sørensen's index as a function of distance between all pairs of sampling stations showed a direct relationship between compositional dissimilarity and distance. That is, the dissimilarity between the polychaete composition from all sampling stations increased with increased distance between them (Figure 4). 


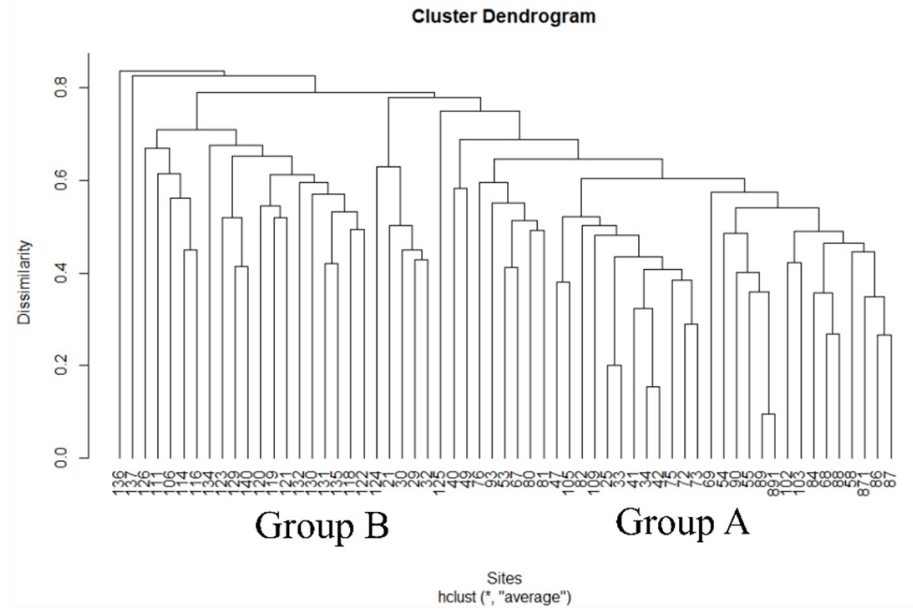

(a)

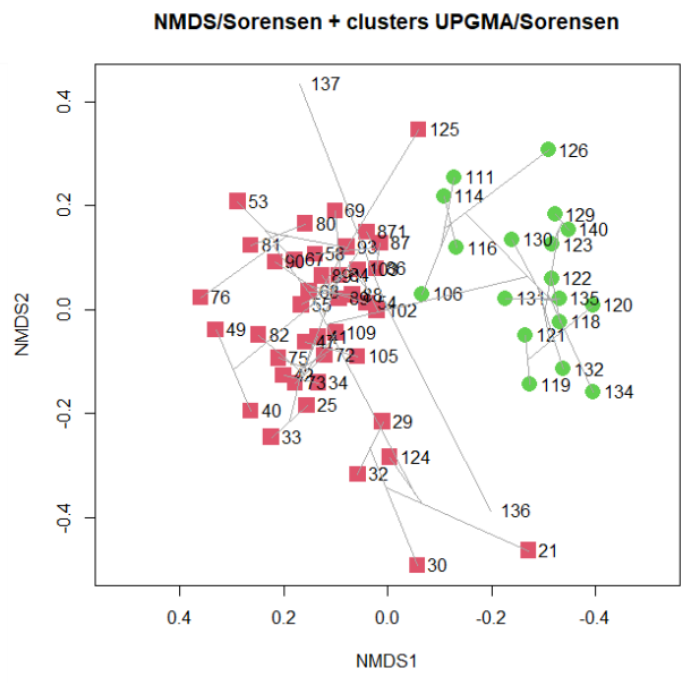

(b)

Figure 3. (a) Cluster analysis based on Sørensen's dissimilarity; (b) Non-metric multidimensional scaling analysis based on Sørensen's dissimilarity (Stress $=0.2$ ). Both analyses show the characterization of two distinct polychaete assemblages on the continental shelf of the Gulf of Mexico. Red squares represent the terrigenous group, green circles group the carbonate stations.

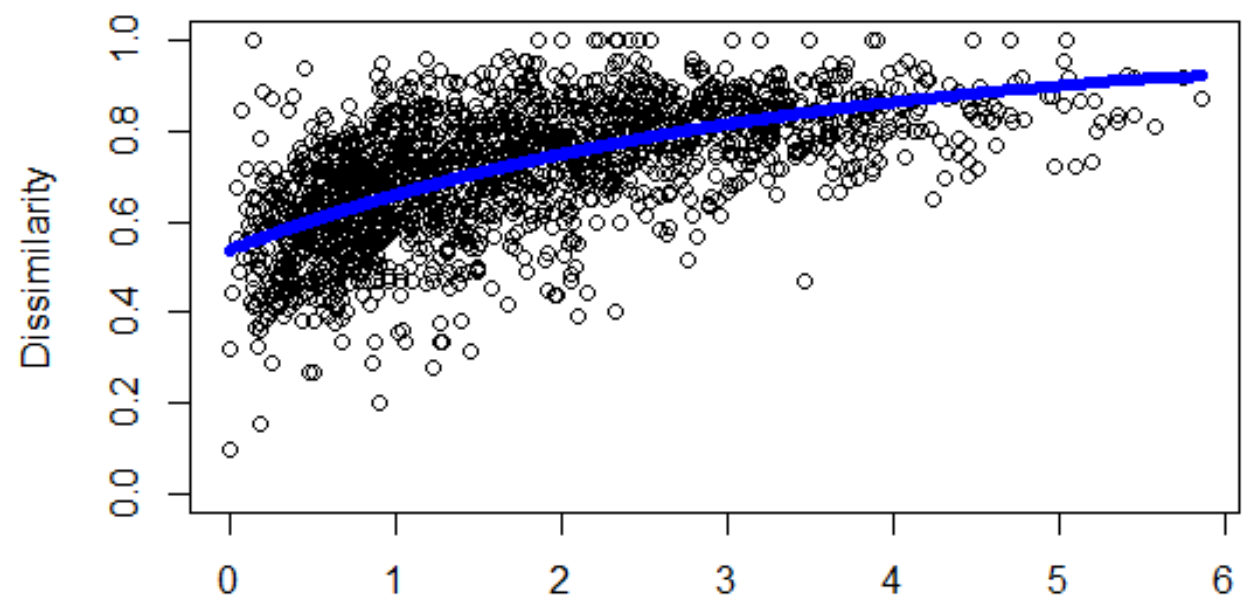

Distance

Figure 4. Sørensen dissimilarity index plotted against distance for all pairwise comparisons between sampling stations. The blue line represents the exponential function describing the increase in dissimilarity (a..intercept $=0.5355325$; b..slope $=0.3067745)$.

\subsection{Distance-Based Redundancy Analysis (dbRDA)}

The distance-based redundancy analysis (dbRDA) showed that the first axis explained $47.34 \%$ of the total variation, and the second axis explained $22.59 \%$. The first two axes together explained $46.8 \%$ of the total variation (Figure 5). The vectors representing mud, salinity, and depth point towards the terrigenous shelf, indicating that by the Western Gulf coasts the stations were mainly muddy, saline, and slightly deeper, whereas the stations on the carbonate shelf in the eastern region were sandy and warm (Figure 5). Stations located in the terrigenous region are depicted in the left upper and lower quadrants and show a great variability, and stations located in the carbonate region are in the upper right and lower right quadrants). 


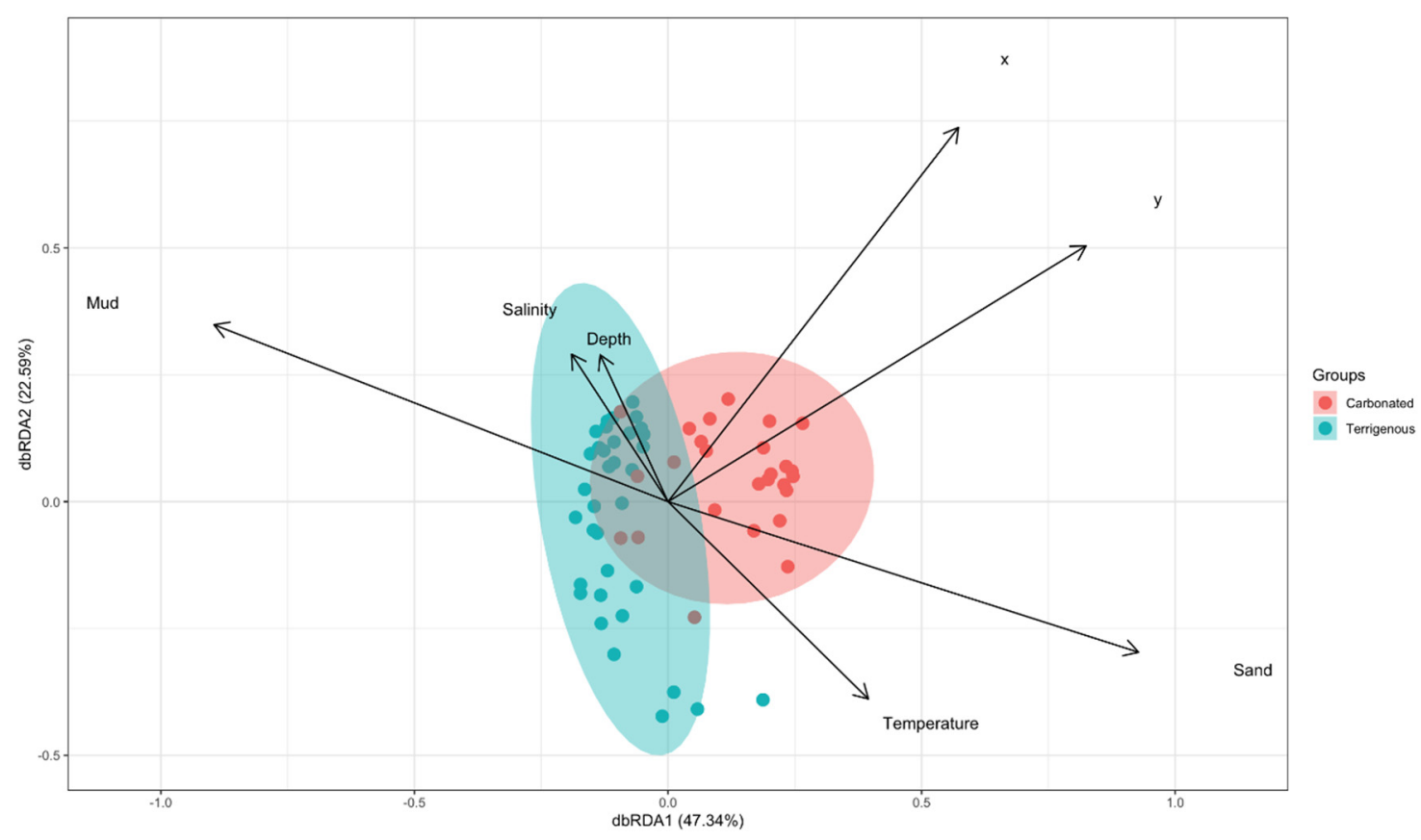

Figure 5. Distance-based redundancy analysis (dbRDA) ordination plot visualizing the relationships between stations based on polychaete composition and the spatial and environmental constraints.

\subsection{Variation Partitioning}

The variation partitioning analysis showed that the combined effects of spatial distribution (X1) and sedimentary composition (X4) primarily explained the variations in species composition across the study area, although the contribution of other variables such as depth (X2) and temperature (X3) was considered. However, salinity contributions were less important and were left off the analysis during the forward selection procedure (Figure 6).

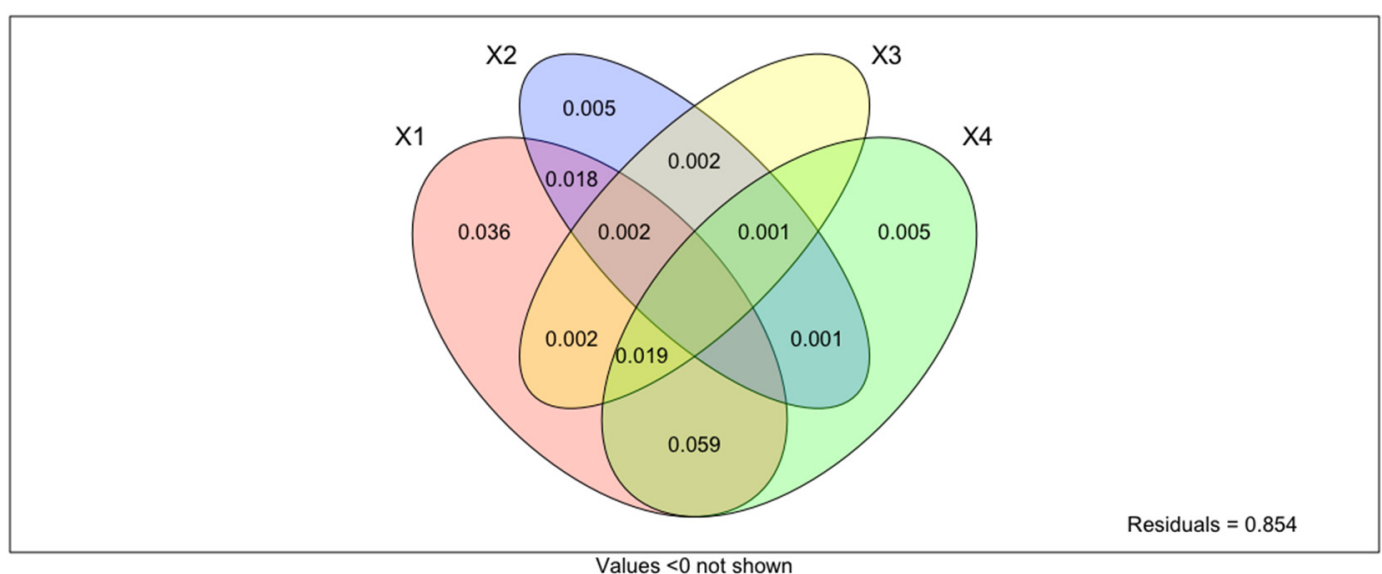

Figure 6. Venn diagrams showing the relative contribution of spatial (X1) and environmental (X2: Depth, X3: Temperature and X4: Sand) components to species distribution.

\section{Discussion}

The present study deepens our understanding of the role of these invertebrates in the established benthic communities of the Campeche Bank area, where the intensive extraction of oil and other hydrocarbons is carried out and the ability to assess the natural and anthropogenic impacts of this industry are important [34,41]. 
Species richness varied across the longitudinal gradient, with an increase in richness from west to east. Two distinct polychaete species assemblages were clearly detected: one corresponding to the terrigenous shelf in the west of the study area, and the other associated with the carbonate shelf in the east. Several studies have shown that sediment composition can be the key factor controlling benthic communities in marine environments [56]. Granados-Barba et al. [57] mentioned that sediment type and depth are the main factors that determine polychaete species distribution and abundance patterns in the Southern Gulf of Mexico. Granados-Barba [58] also showed that depth influences polychaete community structure in the Gulf, with an increase in polychaete species richness with depth.

In our study, the species distribution along the continental shelf of the Southern Gulf of Mexico shows a decline in the number of species from east to west towards the terrigenous shelf. The mixed sandy-mud bottoms, dominant in the Campeche Bank, favor higher species densities and richness, in contrast with the terrigenous sediments from the western Gulf, which negatively affect the development of the benthic communities. Variations in sediment type and grain size determine sediment porosity, which influences the mineralogy, organic matter content, gas, and nutrient concentrations [59-64]. Changes in these sedimentary parameters affect the establishment and development of the benthic organisms, including polychaetes, since the dynamics in the water-sediment interphase modify the excavation processes by organisms and limit the number of species that settle [65]. According to Santibañez-Aguascalientes et al. [66], the carbonate bottoms to the east are constituted of medium and fine calcarenites and oxides that provide suitable habitats for benthic communities $[36,58,67]$. Conversely, terrigenous bottoms that are influenced by fluvial discharges contain mud and sand, and in locations near the mouths of rivers there can be a high diversity of polychaete species that are adapted to turbid bottoms and terrigenous material [68,69].

Our analyses allowed us to distinguish two polychaete assemblages directly related to the terrigenous and carbonate regions in the Gulf of Mexico. This was further confirmed when the distance between sampling stations was considered: where the sampling stations were in geographical proximity, the exchange of polychaete species between the stations increased. The differences observed between the two assemblages can be explained by the dissimilarity in polychaete species composition at the stations as a function of distance separating them. The dbRDA analyses showed that mud/sand content was an important factor structuring the diversity patterns of polychaete fauna. Soft bottoms, owing to their high organic matter content [70] and consistency, facilitate the motility of infaunal species [71] and offer favorable conditions for the establishment of macrobenthic fauna, especially polychaetes. In the Campeche Bank area, previous studies have shown that the distribution and diversity of polychaetes are primarily influenced by sediment composition, with polychaete diversity increasing with higher sand content [34,72]. This sedimentary gradient in our study area showed a west-to-east longitudinal gradient and polychaete species richness followed this same gradient. Depth had, in general, a marginal effect on species composition, being mainly associated with the abrupt bathymetric changes observed in the terrigenous region due to the narrowness of its continental shelf. On the contrary, the carbonate region is linked to a large continental shelf (150 km wide) that is unaffected by river discharge. The establishment and distribution of the local macrobenthic fauna is directly influenced by these factors [34].

Variation partitioning analysis confirmed that the combined effect of spatial structure and sedimentary composition primarily explained the variations in species composition across the study area. The dissimilarities between the terrigenous region and the continental shelf are the result of the mixed influence of geographical distance and changes in sediment composition. A gradual shift from terrigenous (west) to carbonate (east) sediments can be observed, owing to the absence of rivers in the eastern region of the Gulf. A transitional zone, whose limits vary seasonally, can be identified by a mixture of sediments $[59,72]$. Accordingly, the diversity of polychaetes is generally low in the transitional zone, which is 
influenced by the discharge from the Grijalva-Usumacinta river system, high in the east of Campeche Bank. There is also a change in species composition (species turnover) from the terrigenous to the carbonate sediments, with lumbrinerid species present in the terrigenous sediments giving way to spionids in the transitional zone, and sabellids on the carbonate shelf [72].

Our results showed that faunal dissimilarity increased with increasing distance between sampling sites. Exponential models, unlike power law models, involve a constant proportional change of dissimilarity per unit of distance. This implies that the processes governing the distance-decay relationship vary with environmental distance, spatial configuration, and organism attributes, but not with distance independent of these factors. Community dissimilarity at large scales tends to increase with distance due to a combination of various factors, such as higher environmental dissimilarities [49]. In the Southern Gulf of Mexico, depth and other associated characteristics, such as sediment layout and grain size, are believed to have a strong influence on the composition of benthic communities $[59,73]$. Landscape heterogeneity structures biodiversity, setting distinct niches for organisms and driving dissimilarities between communities [74].

Although the sediment is coarse in these regions, high values of organic carbon content were recorded, owing to the high quantity of organic matter discharged by the GrijalvaUsumacinta River, the second-largest river in the Gulf of Mexico (after the Mississippi) [75]. After being deposited in the Gulf, this organic matter is transported towards the east of Campeche Bank by the main current present during the "nortes" season. The local circulation pattern is from east to west along the coastline and is due to the shallow and extended nature of the continental shelf. Low hydrodynamics prevail in the Campeche Bank [37], which favors the deposition of the organic carbon in shallower stations in the east. This pattern creates an environment suitable for surface-deposit-feeders and burrowers in the eastern sandy stations, as has also been mentioned in other studies [76]. The great diversity of habitats in the Gulf of Mexico, due to greater sedimentary and depth heterogeneity, could also be a factor in this increase in diversity from the terrigenous shelf to the carbonate shelf. It is well known that coastal areas with high physical variability have low diversity [76]. This has probably been an influence on the low percentages of variance, explained by the environmental variables.

In this study, the environment was characterized only in terms of spatial processes, depth, and sedimentary characteristics; however, other variables, such as organic matter content, could influence the distribution of polychaetes [77]. Therefore, further studies should be undertaken to explore these relationships, and they may produce higher percentages of variance which can be explained exclusively by environmental structuring [3].

Supplementary Materials: The following are available online at https:/ / www.mdpi.com/article/10 $.3390 /$ d13090425/s1, Figure S1: Spatial distribution of the number of species in the southern Gulf of Mexico., Table S1: List of species of Polychaeta and frequency by region of the southern Gulf of Mexico.

Author Contributions: Conceptualization, B.Q.-M.; methodology, B.Q.-M., P.H.-A., D.A.S.-d.-L. software, B.Q.-M.; validation, B.Q.-M., P.H.-A., D.A.S.-d.-L., V.S.-W.; formal analysis, B.Q.-M., P.H.A., D.A.S.-d.-L., V.S.-W.; investigation, B.Q.-M., P.H.-A., D.A.S.-d.-L., V.S.-W.; resources, B.Q.-M.; data curation, V.S.-W., P.H.-A.; writing-original draft preparation, B.Q.-M.; writing-review and editing, B.Q.-M., P.H.-A., D.A.S.-d.-L., V.S.-W.; visualization, B.Q.-M., P.H.-A., D.A.S.-d.-L., V.S.-W.; supervision, B.Q.-M.; project administration, B.Q.-M.; funding acquisition, B.Q.-M., V.S.-W. All authors have read and agreed to the published version of the manuscript.

Funding: This research was funded by the Universidad Nacional Autónoma de México DGAPA/PAPIIT through the project IA202321 “Análisis y visualización de bases de datos de biodiversidad en sistemas marinos para determinar cambios en los patrones de distribución de la riqueza de especies y la abundancia de la fauna marina del Golfo de México" and through grant 628 from the Instituto de Ciencias del Mar y Limnología, Universidad Nacional Autónoma de México.

Institutional Review Board Statement: Not applicable. 
Informed Consent Statement: Not applicable.

Data Availability Statement: Data are available from the authors upon reasonable request.

Acknowledgments: Thanks are due to all the participants (students, researchers, and crew) of the research expeditions "IMCA" and "DINAMO", carried on out board the R/V "Justo Sierra" (property of the Universidad Nacional Autónoma de México) during which the biological material used in this study was collected. We also thank all the students of the Laboratorio de Ecología y Biodiversidad de Invertebrados Marinos and the Instituto de Ciencias del Mar y Limnología (ICML), UNAM, for their valuable assistance in the processing of samples.

Conflicts of Interest: The authors certify that they have NO affiliations with or involvement in any organization or entity with any financial interest (such as honoraria; educational grants; participation in speakers' bureaus; membership, employment, consultancies, stock ownership, or other equity interest; or expert testimony or patent-licensing arrangements), or non-financial interest (such as personal or professional relationships, affiliations, knowledge, or beliefs) in the subject matter or materials discussed in this manuscript.

\section{References}

1. Dauvin, J.C.; Thiébaut, E.; Gomez-Gesteira, J.L.; Ghertsos, K.; Gentil, F.; Ropert, M.; Sylvand, B. Spatial structure of subtidal macrobenthic community in the Bay of Veys (western Bay of Seine, English Channel). J. Exp. Mar. Biol. Ecol. 2004, 3007, 217-235. [CrossRef]

2. Legendre, P.; Borcard, D.; Peres-Neto, P.R. Analyzing Beta Diversity: Partitioning the Spatial Variation of Community Composition Data. Ecol. Monogr. 2005, 75, 435-450. [CrossRef]

3. Checon, H.H.; Amaral, A.C.Z. Taxonomic sufficiency and the influence of rare species on variation partitioning analysis of a polychaete community. Mar. Ecol. 2017, 38, e12384. [CrossRef]

4. Alves, A.T.; Petsch, D.K.; Barros, F. Drivers of benthic metacommunity structure along tropical estuaries. Sci. Rep. 2020, 10, 1739. [CrossRef]

5. Thrush, S.F.; Hewitt, J.E.; Cummings, V.J.; Norkko, A.; Chiantore, M. $\beta$-Diversity and Species Accumulation in Antarctic Coastal Benthos: Influence of Habitat, Distance and Productivity on Ecological Connectivity. PLoS ONE 2010, 5, e11899. [CrossRef] [PubMed]

6. Giangrande, A.; Gravina, M.F. Brackish-water polychaetes, good descriptors of environmental changes in space and time. Transit. Waters Bull. 2015, 9, 42-55.

7. Mikac, B.; Licciano, M.; Jaklin, A.; Iveša, L.; Giangrande, A.; Musco, L. Diversity and Distribution Patterns of Hard Bottom Polychaete Assemblages in the North Adriatic Sea (Mediterranean). Diversity 2020, 12, 408. [CrossRef]

8. Semprucci, F.; Facca, C.; Ferrigno, F.; Balsamo, M.; Sfriso, A.; Sandulli, R. Biotic and abiotic factors affecting seasonal and spatial distribution of meiofauna and macrophytobenthos in transitional coastal waters. Estuar. Coast. Shelf Sci. 2019, 219, 328-340. [CrossRef]

9. Benedetti-Cecchi, L.; Iken, K.; Konar, B.; Cruz-Motta, J.; Knowlton, A.; Pohle, G.; Castelli, A.; Tamburello, L.; Mead, A.; Trott, T.; et al. Spatial Relationships between Polychaete Assemblages and Environmental Variables over Broad Geographical Scales. PLoS ONE 2010, 5, e12946. [CrossRef] [PubMed]

10. Economo, E.P.; Keitt, T.H. Species diversity in neutral communities: A network approach. Ecol. Lett. 2008, 11, 52-62. [PubMed]

11. Keitt, T.H.; Bjørnstad, O.N.; Dixon, P.M.; Citron-Pousty, S. Accounting for spatial pattern when modeling organism-environment interactions. Ecography 2002, 25, 616-625. [CrossRef]

12. Dormann, C.F.; McPherson, J.M.; Araújo, M.B.; Bivand, R.; Bolliger, J.; Carl, G.; Davies, R.G.; Hirzel, A.; Jetz, W.; Kissling, W.D.; et al. Methods to account for spatial correlation in the analysis of species distribution data: A review. Ecography 2007, 30, 609-628. [CrossRef]

13. Borcard, D.; Legendre, P.; Drapeau, P. Partialling out the Spatial Component of Ecological Variation. Ecology 1992, 73, 1045-1055. [CrossRef]

14. Legendre, P.; Legendre, L. Numerical Ecology, 3rd ed.; Elsevier Science: Amsterdam, The Nederland, 2012.

15. Gilbert, B.; Bennett, J.R. Partitioning variation in ecological communities: Do the numbers add up? J. Appl. Ecol. 2010, 47, 1071-1082. [CrossRef]

16. Heino, J.; Grönroos, M.; Soininen, J.; Virtanen, R.; Muotka, T. Context dependency and metacommunity structuring in boreal headwater streams. Oikos 2012, 121, 537-544. [CrossRef]

17. Knox, G. The role of polychaetes in benthic soft-bottom communities. In Essays on Polychaetous Annelids in Memory of Dr Olga Hartman; Reish, D.J., Fauchald, K., Eds.; Allan Hancock Foundation, University of Southern California: Los Angeles, CA, USA, 1977; pp. 547-604.

18. Hutchings, P.A. Biodiversity and functioning of polychaete in benthic sediments. Biodivers. Conserv. 1998, 7, 1133-1145. [CrossRef] 
19. Arvanitidis, C.; Bellan, G.; Drakopoulos, P.; Valavanis, V.; Dounas, C.; Koukouras, A.; Eleftheriou, A. Seascape biodiversity patterns along the Mediterranean and the Black Sea: Lessons from the biogeography of benthic polychaetes. Mar. Ecol. Prog. Ser. 2002, 244, 139-152. [CrossRef]

20. Capa, M.; Hutchings, P. Annelid Diversity: Historical Overview and Future Perspectives. Diversity 2021, 13, 129. [CrossRef]

21. Grémare, A.; Amouroux, J.M.; Vetion, G. Long-term comparison of macrobenthos within the soft bottoms of the Bay of Banyulssur-mer (Northwestern Mediterranean Sea). J. Sea Res. 1998, 40, 281-302. [CrossRef]

22. Dogan, A.; Çinar, M.E.; Onen, M.; Ergen, Z.; Katagan, T. Seasonal dynamic of soft-bottom zoobenthic communities in polluted and unpolluted areas of Izmir Bay (Aegean Sea). Senckenberg. Marit. 2005, 35, 133-145. [CrossRef]

23. Gambi, M.C.; Giangrande, A. Distribution of soft-bottom polychaetes in two coastal areas of the Tyrrhenian Sea (Italy): Structural Analysis. Estuar. Coast. Shelf Sci. 1986, 23, 847-862. [CrossRef]

24. Mackie, A.S.Y.; Parmiter, C.; Tong, L.K.Y. Distribution and diversity of Polychaeta in the southern Irish Sea. Bull. Mar. Sci. 1997, $60,467-481$.

25. Glasby, C.J.; Read, G. Polychaete worms: A diverse yet poorly known group. Water Atmos. 1998, 6, 7-9.

26. Olsgard, F.; Somerfield, P.J. Surrogates in marine benthic investigations-Which taxonimic unit to target? J. Aquat. Ecosyst. Stress Recover. 2000, 7, 25-42. [CrossRef]

27. Belan, T.A. Marine environmental quality assessment using polychaete taxocene characteristics in Vancouver harbour. Mar. Environ. Res. 2003, 57, 89-101. [CrossRef]

28. Ergen, Z.; Çinar, M.E.; Dagli, E.; Kurt, G. Seasonal dynamics of Soft-Bottom Polychaetes in Izmir Bay (Aegean Sea, Eastern Mediterranean). Sci. Mar. 2006, 70S3, 197-207.

29. Mutlu, E.; Çinar, M.E.; Ergev, M.B. Distribution of soft-bottom polychaetes of the Levantine coast of Turkey, eastern Mediterranean Sea. J. Mar. Syst. 2010, 79, 23-35. [CrossRef]

30. Giangrande, A.; Licciano, M.; Musco, L. Polychaetes as environmental indicators revisited. Mar. Pollut. Bull. 2005, 50, 1153-1162. [CrossRef]

31. Fauchald, K.; Granados-Barba, A.; Solís-Weiss, V. Polychaeta (Annelida) of the Gulf of Mexico. Gulf Mex. Orig. Waters Biota 2009, $1,751-788$.

32. Antoine, J. Structure of the Gulf of Mexico. In Contributions on the Geological and Geophysical Oceanography of the Gulf of Mexico; Rezak, R., Henry, V.J., Eds.; Texas A\&M University: Houston, TX, USA, 1972; Volume 3, pp. 1-34.

33. Martin, R.G.; Bouma, A.H. Physiography of the Gulf of Mexico. In Framework, Fades, and Oil-Trapping Characteristics of the Upper Continental Margin; Bouma, A.H., Moore, G.T., Coleman, J.M., Eds.; American Association of Petroleum Geologists: Tulsa, OK, USA, 1978; Volume 7, pp. 3-19.

34. Hernández-Arana, H.A.; Rowden, A.A.; Attrill, M.J.; Warwick, R.M.; Gold-Bouchot, G. Large-scale environmental influences on the benthic macroinfauna of the southern Gulf of Mexico. Estuar. Coast. Shelf Sci. 2003, 58, 825-841. [CrossRef]

35. Ortiz-Zamora, G.; Huerta-Díaz, M.A.; Salas-de-León, D.A.; Monreal-Gómez, M.A. Degrees of pyritization in the Gulf of Mexico in sediments influenced by the Coatzacoalcos and the Grijalva-Usumacinta rivers. Ciencias Mar. 2002, 28, 369-379. [CrossRef]

36. Carranza-Edwards, A.; Rosales-Hoz, L.; Monreal-Gómez, M.A. Suspended sediments in the southeastern Gulf of Mexico. Mar. Geol. 1993, 112, 257-259. [CrossRef]

37. Monreal-Gómez, M.A.; Salas-de-León, D.A.; Padilla-Pilotze, A.R.; Alatorre-Mendieta, M.A. Hidrografía y estimación de corrientes de densidad en el sur de la Bahía de Campeche, México. Ciencias Mar. 1992, 18, 115-133. [CrossRef]

38. Czitrom, S.P.R.; Ruiz, F.; Alatorre-Mendieta, M.A.; Padilla-Pilotze, A.R. Preliminary study of a front in the Bay of Campeche, Mexico. In Marine Interfaces Ecohydrodynamics; Nihoul, J.C.J., Ed.; Elsevier: Amsterdam, The Netherlands, 1986; pp. 301-311.

39. Salas-de-León, D.A.; Monreal-Gómez, M.A.; Sanvicente-Añorve, L.; Flores-Coto, C. Influence de la circulation à long terme sur la répartition des organismes zooplanctoniques dans la Baie de Campeche, Méxique. Oceanol. Acta 1998, 21, 87-93. [CrossRef]

40. Monreal-Gómez, M.A.; Salas-de-León, D.A. Simulación de la circulación de la Bahía de Campeche. Geofísica Int. 1990, 29 , 101-111. [CrossRef]

41. Hernández-Arana, H.A.; Warwick, R.M.; Attrill, M.J.; Rowden, A.A.; Gold-Bouchot, G. Assessing the impact of oil-related activities on benthic macroinfauna assemblages of the Campeche shelf, southern Gulf of Mexico. Mar. Ecol. Prog. Ser. 2005, 289, 89-107. [CrossRef]

42. Read, G.; Fauchald, K. (Eds.) World Polychaeta Database. 2021. Available online: http://www.marinespecies.org/polychaeta (accessed on 6 August 2021).

43. Baselga, A. Partitioning the turnover and nestedness components of beta diversity. Glob. Ecol. Biogeogr. 2010, 19, 134-143. [CrossRef]

44. Carr, C.M. Polychaete diversity and distribution patterns in Canadian marine waters. Mar. Biodivers. 2012, 42, 93-107. [CrossRef]

45. Sørensen, T. A method of establishing groups of equal amplitude in plant sociology based on similarity of species content. Biol. Skr. 1948, 5, 1-34.

46. Field, J.G.; Clarke, K.R.; Warwick, R.M. A practical strategy for analyzing multispecies distribution patterns. Mar. Ecol. Prog. Ser. 1982, 8, 37-52. [CrossRef]

47. Clarke, K.R.; Warwick, R.M. Change in Marine Communities: An Approach to Statistical Analysis and Interpretation; PRIMER-E: Plymouth, UK, 2001.

48. Clarke, K.R.; Gorley, R.N. Primer v7: User Manual/Tutorial.; Plymouth Marine Laboratory, Ed.; PRIMER-E: Plymouth, UK, 2015. 
49. Nekola, J.C.; White, P.S. The distance decay of similarity in biogeography and ecology. J. Biogeogr. 1999, 26, 867-878. [CrossRef]

50. Nekola, J.C.; McGill, B.J. Scale dependency in the functional form of the distance decay relationship. Ecography 2014, 37, 309-320. [CrossRef]

51. Baselga, A.; Orme, D.; Villeger, S.; De Bortoli, J.; Leprieur, F.; Logez, M.; Henriques-Silva, R. betapart: Partitioning Beta Diversity into Turnover and Nestedness Components R Package Version 1.5.4. 2021. Available online: https://CRAN.R-project.org/ package $=$ betapart (accessed on 6 August 2021).

52. Gómez-Rodríguez, C.; Baselga, A. Variation among European beetle taxa in patterns of distance decay of similarity suggests a major role of dispersal processes. Ecography 2018, 41, 1825-1834. [CrossRef]

53. Blanchet, F.G.; Legendre, P.; Borcard, D. Forward selection of explanatory variables. Ecology 2008, 89, 2623-2632. [CrossRef] [PubMed]

54. Peres-Neto, P.R.; Legendre, P.; Dray, S.; Borcard, D. Variation Partitioning of Species Data Matrices: Estimation and Comparison of Fractions. Ecology 2006, 87, 2614-2625. [CrossRef]

55. R Development Core Team. R: A Language and Environment for Statistical Computing. R Foundation for Statistical Computing: Vienna, Austria. 2020. Available online: https:/ / www.R-project.org/ (accessed on 6 August 2021).

56. Oksanen, J.; Guillaume Blanchet, G.; Friendly, M.; Kindt, R.; Legendre, P.; McGlinn, D.; Minchin, P.R.; O’Hara, R.B.; Simpson, G.; Solymos, P.; et al. Vegan: Community Ecology Package. R Package Version 2.5-7. 2020. Available online: https://CRAN.Rproject.org / package=vegan (accessed on 6 August 2021).

57. Snelgrove, P.V.R.; Butman, C.A. Animal-sediment relationships revisited: Cause versus effect. Oceanogr. Mar. Biol. An. Annu. Rev. 1994, 32, 111-177.

58. Granados Barba, A.; Solís-Weiss, V.; Tovar-Hernández, M.A.; Ochoa-Rivera, V. Distribution and diversity of the Syllidae (Annelida: Polychaeta) from Mexican Gulf of Mexico and Caribbean. Hydrobiologia 2003, 496, 337-345. [CrossRef]

59. Granados Barba, A. Los Poliquetos Bénticos de la Región Petrolera del Suroeste del Golfo de México: Estructura Comunitaria e Impacto Ambiental. Ph.D. Thesis, Facultad de Ciencias, Universidad Nacional Autónoma de México, Mexico City, México, 2001; pp. 149.

60. Gray, J.S. Animal-sediment relationships. Oceanogr. Mar. Biol. An. Annu. Rev. 1974, 12, 223-262.

61. Gray, J.S. The Ecology of Marine Sediments. An Introduction to the Structure and Function of Benthic Communities; Cambridge University Press: Cambridge, UK, 1981.

62. Magni, P.; Tagliapietra, D.; Lardicci, C.; Balthis, L.; Castelli, A.; Como, S.; Frangipane, G.; Giordani, G.; Hyland, J.; Maltagliati, F.; et al. Animal-sediment relationships: Evaluating the 'Pearson-Rosenberg paradigm' in Mediterranean coastal lagoons. Mar. Pollut. Bull. 2009, 58, 478-486. [CrossRef] [PubMed]

63. Magni, P.; Micheletti, S.; Casu, D.; Floris, A.; De Falco, G.; Castelli, A. Macrofaunal community structure and distribution in a muddy coastal lagoon. Chem. Ecol. 2004, 20, 397-409. [CrossRef]

64. Magni, P.; Micheletti, S.; Casu, D.; Floris, A.; Giordani, G.; Petrov, A.N.; De Falco, G.; Castelli, A. Relationships Between Chemical Characteristics of Sediments and Macrofaunal Communities in the Cabras Lagoon (Western Mediterranean, Italy). Hydrobiologia 2005, 550, 105-119. [CrossRef]

65. Díaz-Castañeda, V.; Harris, L.H. Biodiversity and structure of the polychaete fauna from soft bottoms of Bahia Todos Santos, Baja California, Mexico. Deep. Res. II 2004, 51, 827-847. [CrossRef]

66. Santibañez-Aguascalientes, N.A.; Borja, Á.; Montero-Muñoz, J.L.; Herrera-Dorantes, M.T.; Ardisson, P.-L. Setting reference conditions to assess the ecological status of the sublittoral and bathyal benthic communities of the southern Gulf of Mexico. Ecol. Indic. 2020, 111, 105964. [CrossRef]

67. Cuevas Madrid, H.; Rosales Hoz, L.; Márquez García, A.Z.; Carranza Edwards, A. Environmental assessment of a mangrove protected area in the southeast Gulf of Mexico through sediment core analysis. Environ. Earth Sci. 2018, 77, 73. [CrossRef]

68. Santibañez-Aguascalientes, N.A.; Borja, Á.; Kuk-Dzul, J.G.; Montero-Muñoz, J.L.; Ardisson, P.-L. Assessing benthic ecological status under impoverished faunal situations: A case study from the southern Gulf of Mexico. Ecol. Indic. 2018, 91, 679-688. [CrossRef]

69. Hernández-Alcántara, P.; Cortés-Solano, J.D.; Solís-Weiss, V. Polychaete diversity in lagoons and estuaries of the Southern Gulf of Mexico. In Proceedings of the Tenth International Conference on the Mediterranean Coastal Environment, Rhodes, Greece, 25-29 October 2011.

70. Silva, R.F.; Filho, J.S.R.; Souza, S.R.; Souza-Filho, P.W. Spatial and temporal changes in the structure of soft-bottom benthic communities in an Amazon estuary (Caeté estuary, Brazil). J. Coast. Res. 2011, 64, 440-444.

71. Hernández-Alcántara, P.; Avilés-Díaz, A.L.; Solís-Weiss, V. Polychaete diversity patterns along an environmental gradient in Términos Lagoon, a tropical lagoon-estuarine system in the southern Gulf of Mexico. Rev. Mex. Biodivers. 2018, 89, 1115-1126. [CrossRef]

72. Domínguez-Castanedo, N.; Rojas-López, R.; Solís-Weiss, V.; Hernández-Alcántara, P.; Granados-Barba, A. The use of higher taxa to assess the benthic conditions in the southern Gulf of Mexico. Mar. Ecol. 2007, 28, 161-168. [CrossRef]

73. Garrabou, J.; Ballesteros, E.; Zabala, M. Structure and dynamics of north-western Mediterranean rocky benthic communities along a depth gradient. Estuar. Coast. Shelf Sci. 2002, 55, 493-508. [CrossRef]

74. Moritz, C.; Meynard, C.N.; Devictor, V.; Guizien, K.; Labrune, C.; Guarini, J.-M.; Mouquet, N. Disentangling the role of connectivity, environmental filtering, and spatial structure on metacommunity dynamics. Oikos 2013, 122, 1401-1410. [CrossRef] 
75. Yáñez-Arancibia, A.; Day, J.W. Environmental sub-regions in the Gulf of Mexico coastal zone: The ecosystem approach as an integrated management tool. Ocean. Coast. Manag. 2004, 47, 727-757. [CrossRef]

76. Muniz, P.; Pires-Vanin, A.M.S. More about taxonomic sufficiency: A case study using polychaete communities in a subtropical bay moderately affected by urban sewage. Ocean. Sci. J. 2005, 40, 17. [CrossRef]

77. Escobar Briones, E.; Estrada Santillán, E.L.; Legendre, P. Macrofaunal density and biomass in the Campeche Canyon, Southwestern Gulf of Mexico. Deep Sea Res. Part. II Top. Stud. Oceanogr. 2008, 55, 2679-2685. [CrossRef] 